\title{
Maple syrup from Manitoba maple (Acer negundo L.) on the Canadian prairies
}

\author{
by John Kort and Patricia Michiels ${ }^{1}$
}

Manitoba maple (Acer negundo L.), which occurs naturally throughout Saskatchewan and Manitoba and has been planted extensively in prairie shelterbelts, is now beginning to be used to produce maple syrup on a small commercial scale. The product is a light-coloured syrup which has been judged to have a distinctly pleasant flavour. The product is presently sold locally with an emphasis on its distinctiveness of flavour and its origin on the prairies. Studies completed at Indian Head, Saskatchewan show that sap sugar content is slightly less than that of the sugar maple and that its sap flow volume is considerably lower. A three year mean sap yield of $9.8 \mathrm{~L}$ per tap resulted in a syrup yield of $0.23 \mathrm{~L}$ per tap. This is about one quarter to one half of that in a sugar maple.

Key words: Maple syrup, Manitoba maple, prairie shelterbelts
L'érable négondo (Acer negundo L.), que l'on retrouve à l'état naturel en Saskatchewan et au Manitoba et qui a été également planté fréquemment comme brise-vent dans les prairies, est maintenant utilisé à des fins de production commerciale à petite échelle de sirop d'érable. Le produit obtenu est un sirop clair auquel on attribue une agréable saveur distinctive. Le produit est actuellement vendu localement en mettant l'emphase sur le caractère distinct de sa saveur et de son origine des prairies. Les études complétées à Indian Head en Saskatchewan indiquent que le contenu en sucre de la sève est légèrement inférieur à celui de l'érable à sucre et que le volume de sève est considérablement moindre. Un rendement moyen de sève de $9.8 \mathrm{~L}$ par entaille au cours de trois années résultait en une production de $0,23 \mathrm{~L}$ de sirop par entaille. Ce rendement équivaut à un quart à une demie de la production de l'érable à sucre.

Mots clés: sirop d'érable, érable négondo, brise-vent des prairies

\section{Introduction}

Maple syrup was produced by native North Americans before the arrival of the Europeans. Today maple syrup is the basis of a multi-million dollar industry in North America. Farm cash receipts in Canada for maple products in 1989 were reported at \$74.1 million (Statistics Canada 1992). Canada's commercial production of syrup occurs predominantly in Ontario and Quebec. The main maple species which are tapped are sugar maple (Acer saccharum Marsh), red maple (Acer rubrum L.) and silver maple (Acer saccharinum L.).

Manitoba maple (Acer negundo L. var. interius (Britt.) Sarg.), also known as box-elder, is native to the prairies of North America. It is found in moist soils along streams, around lakes and at the margins of swamps, but is considered to be quite drought-tolerant when planted on drier sites (Canada Department of Forestry and Rural Development 1966). Its cold hardiness, drought tolerance and rapid early growth have made it popular on the prairies for street and ornamental plantings and for shelterbelts.

In general, Manitoba maple has not been tapped for maple syrup production on a commercial scale. Lawrence et al.(1993) reported that Manitoba maple has a "typical maple flavour and voluminous thin sap. The last tree a professional sugarmaker would tap but beloved by many backyard tappers." It is likely that it is not used commercially in eastern North America because of the availability of other more desirable maple species. Manitoba maple trees are reported by Overton (1990) to reach a height of $15 \mathrm{~m}$ to $23 \mathrm{~m}$, have a lifespan of 60 years, with a bushy, spreading crown. Under Canadian prairie conditions, its height at maturity is reported to be $14 \mathrm{~m}$ (PFRA Shelterbelt Centre 1989). This is in comparison with the

\footnotetext{
${ }^{1}$ Agriculture and AgriFood Canada, PFRA Shelterbelt Centre, Indian Head, Saskatchewan, Canada S0G 2K0.
}

sugar maple which, in eastern North America, reaches a height of $27 \mathrm{~m}$ to $37 \mathrm{~m}$, has a lifespan of 300 to 400 years and is an upright tree, usually with a single stem (Godman et al. 1990).

Larsson and Jaciw (1967) reported the results of a two-year study done in Ontario in which the sap and syrup of five maple species were compared. They included sugar maple, Manitoba maple, red maple, silver maple and Norway maple (Acer platanoides L.). Average sugar concentration in the sap of Manitoba maple was higher than that of sugar maple in 1964 (3.3\% and $2.6 \%$ respectively). However, since the Manitoba maple trees were street-planted while the sugar maples were in a woodlot, the comparison was made again in 1965 . Streetplanted Manitoba maple had an average of $2.1 \%$ sugar while street-planted sugar maple had 3.9\%. The tree with the highest sugar concentration was a sugar maple with $8.0 \%$ while the sweetest Manitoba maple had $6.3 \%$ sugar. Syrup made from Manitoba maple, Norway maple and sugar maple in 1964 was compared by a panel of judges. The Manitoba maple syrup was rated first by $21 \%$ of the panel while $39 \%$ rated sugar maple syrup first and $40 \%$ rated the Norway maple syrup first. Manitoba maple syrup was considered to have a "distinctly pleasant taste" by $73 \%$ of the judges. In the opinion of the authors, there was a potential to use the Manitoba maple tree for commercial maple syrup production.

Blouin (1992) thought that it was unlikely that the production of maple syrup on the prairies would become a large-scale industry but had the potential to become a "complementary entrepreneurial activity". He did not identify the obstacles to large-scale industrial development. To enhance the economic viability of a prairie enterprise, he suggested that syrup should be distinctively labelled to indicate that it was derived from the Manitoba maple and that it was prairie-produced. As such, it could be distinguished from other maple syrup and could potentially be sold into a niche market. One of Blouin's key 
recommendations was that further research be done to determine the production capability of Manitoba maple

This paper gives a summary of research and recent commercial development activities related to Manitoba maple syrup on the Canadian prairies.

\section{Research on the Prairies}

\section{Sap-sugar Concentrations and Syrup Yields}

Trees were tapped at Indian Head, Saskatchewan (Fig. 1) from 1993 to 1996 to determine sugar concentration and sap flow from typical Manitoba maple trees in the area (Table 1). The trees tapped included trees from eight shelterbelts in five locations near Indian Head. There was a great deal of variability in flow rates (Table 2). Because of differences in location, some of the shelterbelts had greater depths of snow than others and this appeared to be a major factor controlling sap flow. Those trees in an interior row or on the north side of a shelterbelt where snow depth was great and snowmelt was delayed because of shading, began to produce sap later and had a much shorter sap flow season than exposed trees or those on the south side of a shelterbelt. The average sap yield tap ${ }^{-1}$ for four years was $8.8 \mathrm{~L}$. This is in comparison to sap volume from trees in a sugar maple bush which Willits (1965) found to be about $38 \mathrm{~L} \mathrm{tap}^{-1}$. The sap volumes from Manitoba maple shelterbelts achieved so far are therefore considerably lower than those from sugar maple.

Sugar content of individual trees was measured in all four years. Sap subsamples were taken by filling small vials from the sap in the pail at the time of sap collection and measuring them in the laboratory at room temperature with an Atago N10 hand refractometer. Average sugar content of the sap ranged from $3.0^{\circ} \mathrm{Brix}^{2}$ in 1994 to $3.6^{\circ}$ Brix in 1993 . The sap:syrup ratio varied from $34: 1$ to $44: 1$ based on actual sap and syrup volumes. The ratios were poorer than would have been expected from the measured sugar concentration. A $40: 1$ ratio results from a sugar concentration of $2.0-2.2 \%$ (Lawrence et al. 1993; Willits 1965) and sugar maple sap was reported by Lawrence et al. (1993) to contain 2.0-2.75\% sugar. In a 1964 thinning study on sugar maple, Larsson and Jaciw (1967) reported an overall average of $2.6 \%$ sugar. It is possible, therefore, that refractometer readings measured a significant level of solutes other than sugar. Larsson and Jaciw (1967) reported the presence of a variety of dissolved solids other than sucrose in sugar maple sap but sucrose was found to comprise $98 \%$ of the dissolved solids. A more detailed analysis of Manitoba maple sap would be desirable to determine its constituents.

The achieved average annual syrup yields at Indian Head varied from 0.16 to $0.29 \mathrm{~L} \mathrm{tap}^{-1}$ with a four year average of 0.22 L. Jones (1965) (as cited in Larsson and Jaciw 1967) reported that maple trees in Quebec produced an average of about $0.5 \mathrm{~L}$ of syrup per tap based on a survey of 29,000 taps during a ten-year period, while Mason (1990) reported an average taphole yield factor of 5 to 6 , a yield of 0.75 to $0.9 \mathrm{~L} \mathrm{tap}^{-1}$. By these standards, the syrup yield per tap of the Manitoba maple varied from 26 to $46 \%$ of the yields reported earlier.

\footnotetext{
${ }^{2}$ Refractometer readings are expressed as "Brix" - a measure of visual density based on the refraction of light. It may be slightly different from the percent sugar (sucrose) since sap contains sugars other than sucrose and other dissolved compounds.
}

In 1995, sap production was reanalysed on the assumption that the producer was able to recognize unproductive trees which produced less than $5.0 \mathrm{~L}_{\text {of sap year }}{ }^{-1}$. Trees producing $5.0 \mathrm{~L}$

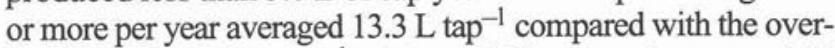
all average of $10.7 \mathrm{~L} \mathrm{tap}^{-1}$. This would increase the syrup yield per tap from $0.24 \mathrm{~L}$ to $0.32 \mathrm{~L}$.

In 1993, the average sugar concentration of a shelterbelt of silver maple at Indian Head was $4.3^{\circ}$ Brix (Table 3 ). Five trees in a shelterbelt of Amur maple (Acer ginnala Maxim.) were also tapped and were found to have an average sugar content of $3.0^{\circ}$ Brix. Manitoba maple sap, therefore, compared favourably with an average sugar content of $3.6^{\circ}$ Brix.

Manitoba maple is a dioecious species so sap sugar was analyzed in 1994 by gender. For 25 male trees and 14 female trees, an LSD test showed no significant difference by gender at the $5 \%$ level.

\section{Closure of Tapholes}

Tapholes made in Manitoba maple trees in 1993 and 1994 were monitored during the two subsequent growing seasons to determine the rate of taphole healing. All of the tapholes were left to heal naturally; none was treated or plugged. The average closure after one growing season was found to be $37.1 \%$ while tapholes were $70.4 \%$ closed after the second growing season (Table 4).

\section{Manitoba Maple Inventory}

In 1993, an inventory of naturally occurring Manitoba maple trees suitable for tapping was conducted in the Qu'Appelle River Valley north of Broadview, Saskatchewan (Fig. 1) because of interest by local entrepreneurs in commercially producing maple syrup there. Thirteen natural stands of Manitoba maple were chosen randomly in the valley along a $25 \mathrm{~km}$ transect. The density of maple trees varied from less than 50 trees ha $\mathrm{h}^{-1}$ to 1300 trees ha-1. There were an estimated 6100 trees that would be suitable for tapping in these thirteen stands. The stands selected for this inventory represented approximately a quarter of the stands which would be suitable for tapping in this area. It was therefore estimated that a total of about 25,000 trees would be suitable for tapping in this $25 \mathrm{~km}$ length of river valley.

From this small inventory and personal observation, it is concluded that there is an abundance of native Manitoba maple in river valleys and other lowlying areas throughout eastern Saskatchewan and southern Manitoba. Tree size appears to increase from west to east within this area, likely due to decreasing drought stress in more easterly areas. The commercial production of Manitoba maple syrup may, therefore, be more economically viable in Manitoba than in Saskatchewan.

\section{Development and Marketing of Manitoba Maple Syrup}

In 1996, there were an estimated 7000 Manitoba maple trees being tapped in Manitoba and Saskatchewan for commercial syrup production. At $0.25 \mathrm{~L}$ of syrup $\operatorname{tap}^{-1}$, this represents a total syrup production of $1750 \mathrm{~L}$ of syrup. Operators reported that it was not difficult to sell all of the product into the local Saskatchewan and Manitoba market. Marketing strategies used included farmers' markets, trade fairs, maple syrup festivals and farmgate sales. Comments by producers indicate that considerable expansion is possible to meet local market demand. 


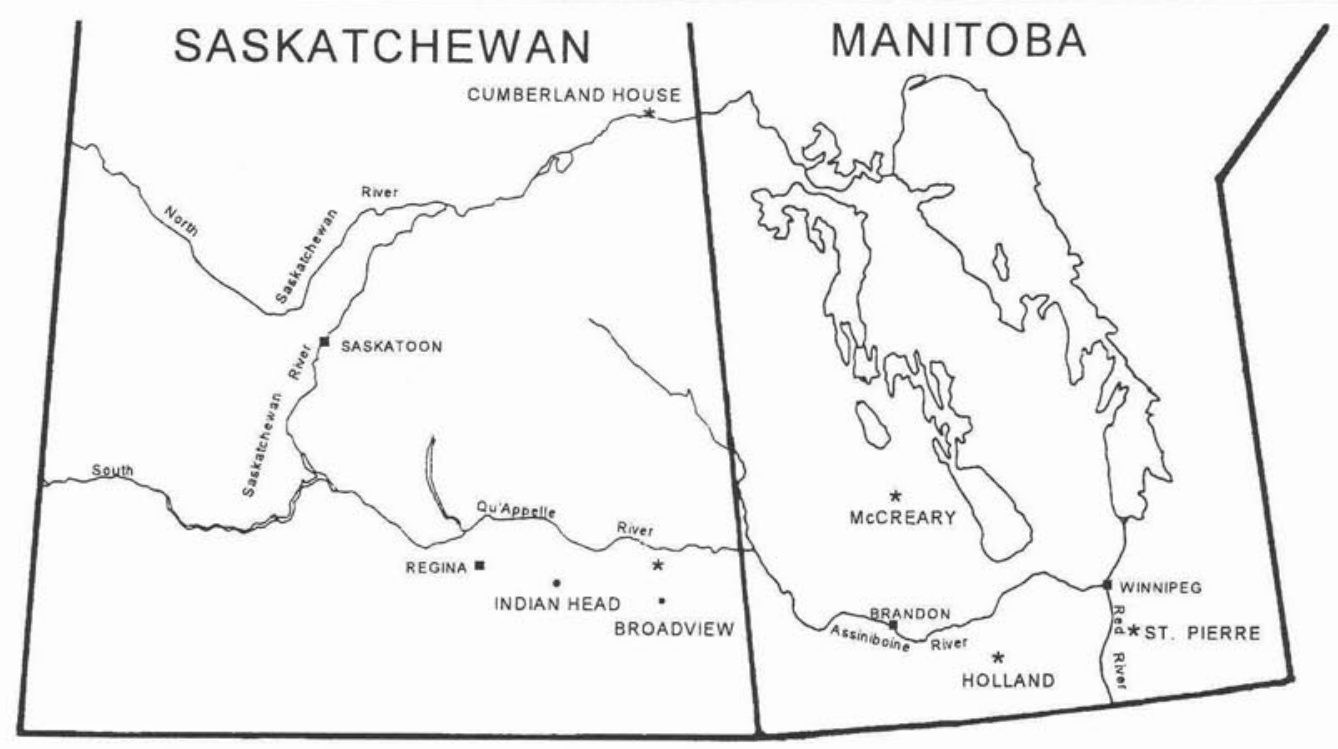

Fig. 1. Map of southern Saskatchewan and Manitoba showing locations of Indian Head and other locations in which maple syrup projects are underway (marked by $\left.{ }^{*}\right)$.

\begin{tabular}{|c|c|c|c|c|c|}
\hline Measurement & 1993 & 1994 & 1995 & 1996 & 4-yr average \\
\hline Total sap volume (L) & 709 & 556 & 904 & 379 & N/A \\
\hline Number of taps & 54 & 95 & 85 & 66 & N/A \\
\hline Mean volume of $\operatorname{sap} \operatorname{tap}^{-1}(\mathrm{~L})$ & 12.9 & 5.9 & 10.7 & 5.7 & 8.8 \\
\hline Mean sugar content in sap $\left({ }^{\circ} \text { Brix }\right)^{1}$ & 3.6 & 3.0 & 3.0 & 3.1 & 3.2 \\
\hline Volume of maple syrup (L) & 16 & 15.5 & 20.7 & 12.2 & N/A \\
\hline Mean volume of syrup tap ${ }^{-1}(\mathrm{~L})$ & 0.29 & 0.16 & 0.24 & 0.18 & 0.22 \\
\hline Sap:Syrup ratio & $44: 1$ & $34: 1$ & $41: 1$ & $31: 1$ & $38: 1$ \\
\hline
\end{tabular}

$1{ }^{\circ}$ Brix is a measure of visual density of sap based on the refraction of light. It differs slightly from \% sugar (sucrose) because sap contains sugars other than sucrose and other dissolved compounds which affect sap density.

Table 2. Sap flow from eight locations near Indian Head, Saskatchewan in which Manitoba maple trees were tapped.

\begin{tabular}{|c|c|c|c|c|c|c|}
\hline \multirow[b]{2}{*}{ Location $^{1}$} & \multirow[b]{2}{*}{ Age } & \multirow[b]{2}{*}{ Position } & \multicolumn{4}{|c|}{ Mean sap $\operatorname{tap}^{-1}(\mathrm{~L})$} \\
\hline & & & 1993 & 1994 & 1995 & 1996 \\
\hline $\mathrm{SCl}$ & 60 & West row & 18.99 & - & - & - \\
\hline $\mathrm{SC} 2$ & 60 & Interior & - & 3.56 & 4.3 & 1.59 \\
\hline $\mathrm{SC} 3$ & 15 & Exposed & - & 5.94 & 12.3 & 3.12 \\
\hline $\mathrm{SC} 4$ & 60 & Exposed & - & - & 13.4 & - \\
\hline EX & 70 & Exposed & 14.17 & 16.38 & 13.6 & 12.91 \\
\hline WIL & 50 & Interior & 9.57 & 3.44 & - & - \\
\hline DEL & 50 & North row \& interior & 10.25 & 5.46 & - & - \\
\hline FAH & 50 & South row & 10.10 & 2.88 & - & - \\
\hline
\end{tabular}

Table 3. Sap flow and sugar contents of three maple species at Indian Head, Saskatchewan in 1993

\begin{tabular}{lccc}
\hline Data collected & Manitoba maple & Amur Maple & Silver maple \\
\hline Total sap collected $(\mathrm{L})$ & 709 & 81.4 & 29.5 \\
No. of trees tapped & 55 & 5 & 5 \\
Mean sap tap ${ }^{-1}$ collected $(\mathrm{L})$ & 12.9 & 16.3 & 4.9 \\
${\text { Mean sap sugar content }\left({ }^{(} \mathrm{Brix}\right)}^{1}$ & 3.6 & 3.0 & 4.3 \\
Volume of syrup produced (L) $_{\text {Mean sap:syrup ratio }}$ & 16.0 & 1.7 & 1.0 \\
\hline
\end{tabular}

$1{ }^{\circ}$ Brix is a measure of visual density of sap based on the refraction of light. It differs slightly from \% sugar (sucrose) because sap contains sugars other than sucrose and other dissolved compounds which affect sap density. 
Table 4. Closure ${ }^{1}$ and healing of tapholes in Manitoba maple after one or two growing seasons at Indian Head, Saskatchewan

\begin{tabular}{lccc}
\hline Growing season & No. of tapholes & Mean closure (\%) & Taps with more than 90\% closure (\%) \\
\hline First season & 147 & 37.1 & 5.4 \\
Second season & 52 & 70.4 & 50.0 \\
\hline
\end{tabular}

${ }^{1}$ Percent closure estimate based on the following formula:

$\%$ closure $=100-[(W / 2) \times(\mathrm{L} / 2) \times \pi \times 100] /\left[r^{2} \times \pi\right]$

Where: $W=$ the measured width of the hole $(\mathrm{mm}), L=$ the measured length of the hole $(\mathrm{mm}), r=$ the original radius of the hole $(6 \mathrm{~mm})$.

Producers agreed that it was important to ensure quality, and to emphasize the uniqueness and distinct flavour of the product. Product was sold predominantly in small containers to make it suitable for gift-giving. This ensured that the producers received the best price for the product.

There is also a great deal of interest in hobby-scale production of maple syrup. The need for information and supplies, both by commercial and hobby-scale producers, has resulted in the establishment of a distributorship for maple syrup supplies for the prairies.

\section{Summary and Conclusions}

Manitoba maple produces a unique, pleasant syrup which is commercially saleable. The sugar content of the sap is slightly less sweet than that of sugar maple. Due to the smaller size of the tree, the four year average sapflow at Indian Head, Saskatchewan, produced only enough sap to make $0.22 \mathrm{~L} \mathrm{tap}^{-1}$ of syrup, between one-quarter and one-half that reported for sugar maple.

A small but growing maple syrup industry exists in Manitoba and Saskatchewan. The commercial feasibility will depend on the price that producers can achieve for the product. More hobbyscale production is developing as landowners become aware of the possibility of making maple syrup from Manitoba maple.

\section{References}

Blouin, G. 1992. Manitoba maple — an untapped resource. A preliminary report on the feasibility of developing a viable industry in the Canadian prairie provinces based on the utilization of products derived from the sap of Manitoba maple (Acer negundo L.). CanadaSaskatchewan Partnership Agreement in Forestry. Minister of Supply and Services Canada. 1992.

Canada Department of Forestry and Rural Development. 1966. Native trees of Canada. Queen's Printer, Ottawa, ON.

Godman, R.M., H.W. Yawney and C.H. Tubbs. 1990. Acer saccharum Marsh. Sugar maple. pp. 78-91 In: Silvics of North America. Volume 2. Hardwoods. R.M. Burns and B.H Honkala (Eds.). USDA Agriculture Handbook 654.

Jones, A.R.C. 1965. Maple research and demonstrations. The Morgan Arboretum and Woodland Development Association. MacDonald College, Annual Report: 8-13, Montreal, QC.

Larsson, H.C. and P. Jaciw. 1967. Sap and syrup of five maple species. Research report No. 69. Ontario Department of Lands and Forests. Lawrence, J.L., R. Martin and P.O. Boisvert. 1993. Sweet maple. Life, lore and recipes from the sugarbush. Chapters Publ. Shelburne, Vermont.

Overton, R.P. 1990. Acer negundo L. Boxelder. pp.41-45 In: Silvics of North America. Volume 2. Hardwoods. R.M. Burns and B.H Honkala (Eds.). USDA Agriculture Handbook 654.

PFRA Shelterbelt Centre. 1989. Shelterbelt species. TN CIR 6-89. Agriculture Canada.

Statistics Canada. 1992. Canada year book 1992. Statistics Canada, Ottawa, ON. p 367.

Willits, C.O. 1965. Maple syrup producers manual. USDA Agriculture Handbook No. 134. 